Przegląd Narodowościowy / Review of Nationalities • nr 7/2017 • World of Slavs / Świat Słowian

\title{
The Gypsy Baron Operetta (1885) as a musical document of a certain age
}

Operetka Baron cygański (1885)

jako muzyczny dokument pewnej epoki

Keywords: Maria Theresa, operetta, The Gypsy Baron (Der Zigeunerbaron), Gypsies in music, Johann Strauss II

Popular culture, including popular music, is a field not often associated with political efforts to consolidate particular goals, such as those related to the maintenance of dynastic interests. And yet in the second half of the nineteenth century, the Viennese musical theater, especially the operetta theater, became a venue for the dissemination of certain political content. It can be even argued that the image of reality created by the Vienna operetta served to strengthen the sense of unity of the great Habsburg monarchy, weakened by the armed conflict with Prussia in 1866, and also with the problems resulting from ethnic heterogeneity of its inhabitants.

This thesis on the propaganda role of Viennese operetta theater in the second half of the $19^{\text {th }}$ century will be illustrated in this article by an example of a work popular up till now, which is undoubted-
Słowa kluczowe: Maria Teresa, operetka, Baron Cygański, Cyganie w muzyce, Johann Strauss II

Kultura popularna, w tym muzyka popularna, to dziedzina nieczęsto kojarzona z politycznymi zabiegami zmierzającymi do konsolidacji partykularnych celów, np. związanych z utrzymaniem interesów dynastycznych. A jednak w drugiej połowie XIX w. wiedeński teatr muzyczny, a zwłaszcza operetkowy, stał się miejscem upowszechniania pewnych politycznych treści. Można wręcz twierdzić, że kreowany przez świat wiedeńskiej operetki obraz rzeczywistości służył umocnieniu poczucia jedności wielkiej habsburskiej monarchii, osłabionej konfliktem zbrojnym z Prusami z roku 1866, a także borykającej się z problemami wynikającymi z niejednorodności etnicznej zamieszkujących ją obywateli.

Tak postawiona teza o propagandowej roli wiedeńskiego teatru operetkowego drugiej połowy XIX w. zostanie zilustrowana $\mathrm{w}$ niniejszym artykule przykładem

* Correspondence address: Instytut Muzykologii Uniwersytetu Jagiellońskiego, ul. Westerplatte 10, 31-033 Kraków, e-mail: agpiotrowska@interia.pl. 
ly the Gypsy Baron (1885). Not only the very context of the origins of this operetta and the heroes portrayed in it are indicative of the conscious efforts of its creators to create a work of propaganda values, even educatory. No less important are - not always articulated, but suggested during the operetta - references to the luminous past of the Empire. In particular, the figure of Maria Theresa is displayed, although she herself does not appear in the operetta. But her 'presence' is noticeable both in the textual and the (indirect) musical layers. In $19^{\text {th }}$-century Vienna not only Maria Teresa was still remembered, but in a certain way also her rule from 1740-1780 was mythologized, which for some reason was considered to be one of the most favorable for Austria. The awarness the heritage of these times permeated the imagination of musicians, writers, journalists, and they reached to wider audiences of popular culture.

The Gypsy Baron opera itself, although in a veiled manner, finally reveals and confirms the significance of Maria Theresa's character for the popular culture of $19^{\text {th }}$. century Vienna and the entire Empire. The action of this work was settled in the $18^{\text {th }}$ century, during the warfare conducted by Austria. There is a war between Austria and the Turks (the Belgrade siege of 1717 is also mentioned here). However, the war for Austrian succession (1740-1748) is crucial for the fate of heroes. Although not quite straightforward, the audience learns that then a great multinational army fought for Maria Theresa. As it is known, after the death of Charles VI on 20 October 1740, Maria Theresa became the Archduchess of popularnego do dziś dzieła, jakim niewątpliwie jest Baron cygański (1885). Nie tylko bowiem sam kontekst powstania tej operetki oraz uwiecznieni $\mathrm{w}$ niej bohaterowie świadczą o świadomych zabiegach jej twórców, by stworzyć dzieło o walorach propagatorskich, wręcz edukujących. Nie mniej istotne wydają się - nie zawsze wyraziście artykułowane, ale zasugerowane w trakcie operetki - nawiązania do świetlistej przeszłości Imperium. W szczególności wyeksponowana zostaje postać Marii Teresy, chociaż ona sama nie pojawia się w operetce. Ale jej „obecność” wyczuwalna jest zarówno w warstwie tekstowej, jak i (pośrednio) muzycznej. W XIX-wiecznym Wiedniu nie tylko wciąż pamiętano o Marii Teresie, ale w pewien sposób także mitologizowano jej rządy z lat 1740-1780, które przecież nie bez powodów uważano za jedne z najkorzystniejszych dla Austrii. Świadomość dziedzictwa tych czasów przenikała więc wyobraźnię muzyków, literatów, dziennikarzy, a za ich sprawą docierała do szerszych kręgów odbiorców kultury popularnej.

Sama operetka Baron cygański, mimo że w zawoalowany sposób, ostatecznie ujawnia i potwierdza, jakie znaczenie miała postać Marii Teresy dla popularnej kultury XIX-wiecznego Wiednia, a także całego Imperium. Akcja tego dzieła osadzona została bowiem w wieku XVIII - w czasie działań wojennych prowadzonych przez Austrię. Mowa tu o wojnie pomiędzy Austrią a Turkami (wspomniane jest też oblężenie Belgradu z 1717 r.). Jednak kluczowa dla losów bohaterów okazuje się Wojna o Austriacką Sukcesję (1740-1748). Choć niezupełnie wprost, publiczność jednak 
Austria, the Queen of the Czech Republic and Hungary, in addition to the ruler of the Austrian Netherlands, Duchess of Milan and Mantua, and Parma and Piacenza. However, the Bavarian elector Karol Albrecht also claimed the title. It was only after securing the throne that Maria Theresa, as an enlightened ruler, began to undertake a series of reforms. And the operetta also refers to them, showing the legacy of Maria Theresa's actions on the ground of overthrowing superstitions, or faith in miracles and vampirism. Moreover, making Gypsies one of the main characters of the operetta, and portraying them in a specific, rather positive, way, clearly highlights the continuity of the tradition of change that just begun in Austria by Maria Theresa. Although the character of Maria Theresa is mentioned by the operetta characters, she does not appear on stage. But it seems that one can talk about her alter ego, because Saffi, one of the main characters, shows a lot of similarities with Maria Theresa, or at least their life situations have a lot in common. Ignored, even despised Saffi not only turns out to be a true aristocrat, but also is recognized by others as the full heir of his ancestors. Such a happy transformation of the girl's fate can easily be read as an allusion to the fate of Maria Theresa. dowiaduje się, że wówczas to wielka, wielonarodowa armia walczyła dla Marii Teresy. Jak wiadomo bowiem, po śmierci Karola VI 20 października 1740 r. Maria Teresa stała się arcyksiężną Austrii, a także królową Czech i Węgier, ponadto władczynią Niderlandów Austriackich, księżną Mediolanu i Mantui oraz Parmy i Piacenzy. Jednak pretensje do tytułów zgłosił także elektor bawarski Karol Albrecht. Dopiero po zapewnianiu praw do tronu, Maria Teresa - jak przystało na oświeconego władcę - przystąpiła do przeprowadzenia wielu reform. I także do nich nawiązuje operetka, ukazując spuściznę poczynań Marii Teresy na gruncie obalania zabobonów czy też wiary w cuda i wampiryzm. Co więcej, uczynienie z Cyganów jednych z głównych bohaterów operetki, a także sportretowanie ich w specyficznym - raczej pozytywnym - świetle wyraźnie podkreśla ciągłość tradycji zmian zapoczątkowanych w Austrii właśnie przez Marię Teresę. Chociaż sama postać Marii Teresy jest wspominana przez bohaterów operetki, nie pojawia się ona na scenie. Ale wydaje się, że można mówić o jej alter ego, gdyż Saffi - jedna z głównych bohaterek - wykazuje sporo istotnych podobieństw z Marią Teresą, a przynajmniej ich życiowe sytuacje mają ze sobą wiele wspólnego. Ignorowana, wręcz pogardzana Saffi nie tylko okazuje się prawdziwą arystokratką, ale także zostaje uznana przez pozostałych za pełnoprawną spadkobierczynię swoich przodków. Taką szczęśliwą przemianę losów dziewczyny łatwo można odczytać jako aluzję do losów Marii Teresy. 


\section{Gypsy Baron: Context of the creation of the work}

The Gypsy Baron is not only the crowning work of Strauss, but also one of the world's most popular operettas, often played to this day ${ }^{1}$. Its premiere took place on 24 October 1885 at the Vienna Theater an der Wien, and the work met with enthusiastic reception as it was conceived as a "patriotic spectacle"2. The performance was a success both for composer Johann Strauss II (1825-1899) and for librettist Ignaz Schnitzer (1839-1921). In their intention, this operetta was a work inscribed into a specific political situation after the 1867 Compromise which was reached by urbanized and industrialized Austria and more agricultural Hungary ${ }^{3}$. The Hungarian nation itself was particularly esteemed in Austria, appreciating the rebellious and independent nature of the Hungarians, and the political and economic regulations of the 1867 Compromise provided the same legal framework for Austria and Hungary. In practice, this meant a real increase in investment, attracting increased interest in the economy, as well as the Hungarian culture. Undoubtedly, the Gypsy Baron was part of the effort to bring the wealth of Hungarian folklore closer to the Viennese, while preserving the proportion of presentation of both parts of the Hungarian and Austrian empire in a state of not

${ }^{1}$ R. Traubner, Operetta. A Theatrical History, New York, 2003, p. 129 ("The score of the Gypsy Baron is generally rated Strauss's number two work, directly after Die Fledermaus").

2 L. Kydryński, J. Strauss, Kraków 1985, p. 229.

3 See: A.G. Piotrowska, Topos muzyki cygańskiej $w$ kulturze europejskiej od końca XVIII do początku XX wieku, Kraków 2011, pp. 251-266.

\section{Baron cygański: kontekst powstania dzieła}

Baron cygański to nie tylko koronne dzieło w dorobku Straussa, ale także jedna z najbardziej popularnych na świecie operetek, często grywana do dziś1. Jej premiera odbyła się 24 października 1885 r. w wiedeńskim Theater an der Wien, a dzieło spotkało się z entuzjastycznym przyjęciem, gdyż pomyślane było jako „patriotyczny spektakl”2. Przedstawienie stało się sukcesem zarówno kompozytora - Johanna Straussa II (18251899), jak i librecisty - Ignaza Schnitzera (1839-1921). W ich zamierzeniu operetka ta była dziełem wpisującym się w specyficzną sytuację polityczną po Kompromisie z 1867 r. zawartym pomiędzy zurbanizowaną i uprzemysłowioną Austrią a bardziej rolniczymi Węgrami ${ }^{3}$ Sam naród węgierski darzono w Austrii szczególną estymą, doceniając buntowniczy i niezależny charakter Węgrów, a polityczne i ekonomiczne regulacje Kompromisu z 1867 r. zapewniały tożsame regulacje prawne dla Austrii i Węgier. W praktyce oznaczało to realny wzrost inwestycji, pociągając za sobą zwiększone zainteresowanie ekonomią, a także kulturą węgierską. Niewątpliwie więc Baron cygański wpisywał się w działania zmierzające do przybliżenia Wiedeńczykom bogactwo folkloru Węgier, przy jednoczesnym zachowaniu proporcji prezentowania obydwu części imperium - węgierskiej i austriackiej -

${ }^{1}$ R. Traubner, Operetta. A Theatrical History, New York 2003, s. 129 („The score of the Gypsy Baron is generally rated Strauss's number two work, directly after Die Fledermaus").

2 L. Kydryński, J. Strauss, Kraków 1985, s. 229.

${ }^{3}$ Por. A.G. Piotrowska, Topos muzyki cygańskiej $w$ kulturze europejskiej od końca XVIII do poczatku XX wieku, Kraków 2011, s. 251-266. 
only perfect harmony, but also a joint action. It could be said that the operetta was part of the theatrical concept of portraying the "enthusiastic participation of the Hungarian side in imperial policy"4 and was thus considered "the musical monument to the Austro-Hungarian Empire" 5 . This was a proposal calculated for heating up procivic attitudes welcome in a country inhabited, among others, by Austrians, Hungarians, Romanians, Germans, Slovaks, Serbs, Croats or the so-called 'others', including Jews and Gypsies ${ }^{6}$. Thus, the whole gallery of characters, including Hungarians, Gypsies, Austrians, was introduced to the operetta, and even the Turks were mentioned, but focusing on showing their mutual relations. At first, they are not the best, even hostile, but over time they are greatly improved, in the end, in the name of the good of the motherland under the rule of $\mathrm{Ma}$ ria Theresa, they lead to the cooperation of once-feuding heroes. Thus, the Gypsy Baron glorified the idea of a multi-ethnic state, emphasizing the importance of unselfish cooperation on its good. Monarchy was portrayed as a zone of interwoven interests of the Habsburg dynasty and numerous centers inhabiting Central Europe.

There is no doubt that the Gypsy Baron was in line with the official efforts made to create a particular image of the monarchy as a happy, multinational state of

\footnotetext{
4 C. Crittenden, Johann Strauss and Vienna. Operetta and the Politics of Popular Culture, Cambridge 2000, p. 175 ("enthusiastic Hungarian participation in imperial politics").

5 R. Traubner, op. cit., p. 111 ("a musical monument to the Austro-Hungarian Empire").

6 A. Gergely, Z. Szasz, Kiegyezes utan, Budapest 1978, p. 111.
}

w stanie nie tylko idealnej harmonii, ale i wspólnego działania. Można powiedzieć, że operetka wpisywała się w teatralne koncepcje portretowania „entuzjastycznej partycypacji strony węgierskiej w polityce imperialnej”", uznano ją więc za „muzyczny pomnik Austro-węgierskiego Imperium"s. Była to propozycja obliczona na podgrzewanie proobywatelskich postaw mile widzianych w państwie zamieszkiwanym m.in. przez Austriaków, Węgrów, Rumunów, Niemców, Słowaków, Serbów, Chorwatów czy tzw. innych, w tym Żydów i Cyganów ${ }^{6}$. Do operetki wprowadzono zatem cała galerię postaci, w tym Węgrów, Cyganów, Austriaków, wspomniano nawet Turków, ale skoncentrowano się zwłaszcza na ukazaniu ich wzajemnych relacji. Zrazu są one nie najlepsze, nawet wrogie, lecz z czasem ulegają znacznej poprawie, by ostatecznie - w imię dobra ojczyzny pod panowaniem Marii Teresy - doprowadzić do współpracy zwaśnionych niegdyś bohaterów. A zatem w Baronie cygańskim gloryfikowano ideę wieloetnicznego państwa, podkreślając ważkość bezinteresownego współdziałania na jego rzecz. Monarchię portretowano jako strefę splatających się interesów dynastii Habsburgów oraz licznych narodów zamieszkujących tereny Europy Środkowej.

Nie ulega wątpliwości, że Baron cygański wpisywał się w nurt oficjalnych wysiłków podejmowanych w celu wykreowa-

${ }^{4}$ C. Crittenden, Johann Strauss and Vienna. Operetta and the Politics of Popular Culture, Cambridge 2000, s. 175 („enthusiastic Hungarian participation in imperial politics").

${ }^{5}$ R. Traubner, op. cit., s. 111 („a musical monument to the Austro-Hungarian Empire”).

${ }^{6}$ A. Gergely, Z. Szasz, Kiegyezes utan, Budapest 1978, s. 111. 
common aspirations and endeavors. At the same time, the so-planned work of popular culture legitimized the power of the Habsburgs. by emphasizing the unifying role of Maria Theresa, whose government contributed to the consolidation of the army. Officially endorsed images of the monarchy were duplicated on the operetta scene ${ }^{7}$, appealing to not so ancient past, while updating the context of the transmission of these historical contents. In such works as the Gypsy Baron, the history of the Habsburgs was not only reminiscent but also adapted to a particular situation, fueling among the citizens of the Empire the awareness of the bright past of their homeland. In the magazine Das Vaterland in 1910, significant opinion in that context was presented that the Gypsy Baron "for the sake of the text, but even more for the sake of music, is a national, patriotic [...] classic work" . And although the operetta today seduces mainly with musical values - arias of great melodic language and great instrumentation, its charm, however, must also be found in such elements as colorful costumes or the presence of live dances, and see its influence as a musical document of the already past times.

7 See: Politische Mythen und nationale Identitäten im (Musik-)Theater: Vorträge und Gespräche des Salzburger Symposiums 2001, edit. P. Scobadi, vol. 2, Anif-Salzburg 2003.

${ }^{8}$ Das Vaterland, 27 December 1910. Cited from C. Crittenden, op. cit., p. 170 ("On account of its text, but even more on account of the music, it is a national, patriotic, a true Austria and Viennese work of classical character"). nia określonego obrazu tejże monarchii jako szczęśliwego, wielonarodowego państwa połączonego wspólnymi aspiracjami i dążeniami. Jednocześnie tak pomyślane dzieło kultury popularnej legitymizowało władzę Habsburgów, m.in. poprzez podkreślenie jednoczącej roli Marii Teresy, której rządy przyczyniły się do konsolidacji armii. Oficjalnie aprobowane wyobrażenia na temat monarchii duplikowano na scenie operetkowej ${ }^{7}$, odwołując się do nie tak dawnej przeszłości, jednocześnie uaktualniając kontekst przekazu owych historycznych już treści. W takich dziełach jak $B a$ ron cygański dzieje Habsburgów nie tylko na nowo przypominano, ale także adaptowano do konkretnej sytuacji, podsycając wśród obywateli Imperium świadomość świetlanej przeszłości ich ojczyzny. W piśmie Das Vaterland z 1910 r. padły znamienne w tym kontekście słowa, że Baron cygański „ze względu na tekst, ale jeszcze bardziej za względu na muzykę, to narodowe, patriotyczne, [...] dzieło o klasycznym charakterze"s. I chociaż operetka dzisiaj uwodzi głównie walorami muzycznymi wielką melodyjnością arii oraz świetną instrumentacją, jednak jej uroku szukać także należy w takich elementach jak barwne kostiumy czy obecność żywych tańców oraz upatrywać w jej oddziaływaniu jako muzycznego dokumentu pewnej minionej już epoki.

\footnotetext{
7 Por. Politische Mythen und nationale Identitäten im (Musik-)Theater: Vorträge und Gespräche des Salzburger Symposiums 2001, red. P. Scobadi, vol. 2, Anif-Salzburg 2003.

${ }^{8}$ Das Vaterland, 27 grudnia 1910 r. Cyt. za C. Crittenden, op. cit., s. 170 („On account of its text, but even more on account of the music, it is a national, patriotic, a true Austria and Viennese work of classical character").
} 


\section{Gypsy Baron: the history of love in troubled times}

Under the influence of his third wife Adele Deutsch, Strauss read the short story published in 1883 by the Hungarian writer Mór Jókai (1825-1904) entitled Saffi. Its author ranked among the esteemed authors of romantic novels in his country, at the same time he was also considered a great Hungarian patriot. He was among others a friend of Sandor Petöfi, a participant of the fighting of 1849, and also (for over thirty years) a parliamentarian. His story so inspired Strauss that it became the basis for the libretto of his next operetta just being composed. This is happening in the middle of the $18^{\text {th }}$ century during the rule of Maria Theresa and concerns the fate of a girl raised in a Gypsy caravan, who - after all not being a true Gypsy - takes over the system of values of her guardians. Moreover, just as the Gypsy she finds the true love of her life. Her darling is Sándor Barinkay, whose family was once exiled for cooperation with the Turks. So, when Barinkay returns home, he tries to regain his fortune. However, it turns out that the property fell into ruin. Even worse, the neighboring pig farmer, Kálmán Zsupán, desires these goods. Undaunted, entrepreneurial Zsupán finds, as he seems perfect, the solution to the situation. He suggests that Barinkay marry his beloved daughter Arsenna. In this clever way, the swineherd would have kept the property, and the daughter had a well-born husband. Zsupán did not foresee, however, that Arsen was already - and mutually - in love with Ottokar, the son of his

\section{Baron cygański: dzieje miłości} w niespokojnych czasach

Pod wpływem swojej trzeciej żony Adeli Deutsch, Strauss zapoznał się z wydaną w 1883 r. nowelą autorstwa węgierskiego pisarza Mora Jokai'a (1825-1904) zatytułowaną Saffi. Jej autor zaliczał się do cenionych w swoim kraju autorów powieści romantycznych, jednocześnie uchodził też za wielkiego węgierskiego patriotę, był m.in. przyjacielem Sandora Petöfiego, uczestnikiem walk z 1849 r., a także (przez ponad 30 lat) parlamentarzystą. Jego powiastka tak zainspirowała Straussa, że stała się ona kanwą libretta projektowanej właśnie jego kolejnej operetki. Rzecz dzieje się w połowie XVIII w. podczas rządów Marii Teresy i dotyczy losów dziewczyny wychowanej w taborze cygańskim, która - nie będąc przecież prawdziwą Cyganką - przejmuje jednak system wartości swych opiekunów. Co więcej, właśnie jako Cyganka odnajduje prawdziwą miłość swojego życia. Jej wybranek to Sándor Barinkay, którego rodzina została niegdyś wygnana za współpracę z Turkami. Kiedy więc Barinkay powraca w rodzinne strony, próbuje odzyskać majątek. Okazuje się jednak, że posiadłości popadły w ruinę. Co gorsza, sąsiadujący z włościami hodowca świń, Kálmán Zsupán, ma chrapkę na te dobra. Niczym niezrażony, przedsiębiorczy Zsupán znajduje jak mu się wydaje - doskonałe rozwiązanie zaistniałej sytuacji. Proponuje bowiem, by Barinkay pojął za żonę jego ukochaną córkę Arsenę. W ten oto sprytny sposób świniarz zachowałby majątek, a córka zyskała dobrze urodzonego męża. Zsupán nie przewidział jednak, że Arsena jest już - i to ze 
governess Mirabella. So unhappy with the prospect of a wedding with the candidate imposed on her, Arsena declares that she will marry only a count or baron. Barinkay feels rejected and follows the Gypsy camp to find true friends among the Gypsies. The Gypsies remember that Barinkaya's father, contrary to all, always favored them, and now they return a favor hosting his son. They even declare him their leader by calling him a 'baron'. Impressed with the gypsies' attitude, Barinkay decides to join them well and ties down to a beautiful Gypsy girl Saffi. Her mother Chipra is an old and wise Gypsy respected by the band. Inspired by the prophetic dream, she tells them where the treasure is hidden, buried during the Turkish occupation. In the meantime, Count Homonay arrives with the intention of recruiting men into the army and confiscate a treasure for military needs. The confiscation of the treasure seems obvious, because - as historians affirm - "the war for succession absorbed a great deal of financial resources". But first and foremost, it turns out that Saffi, the newly married wife of Barinkaya, is not at all a Gypsy, but an authentic princess. In this situation, Barinkay feels he must earn the title of her husband. He joins the army with the other men and they all go to war. After a successful campaign, they return to Vienna to meet their beloved and celebrate the victory together and a bright future under Maria Theresa's protectorate.

It is possible in this way to summarize the action of the operetta, which begins

9 R.W. Kowalczyk, Polityka fiskalna i gospodarcza Józefa II, "Studia z historii społeczno-gospodarczej" 2011, vol. 9, p. 7. wzajemnością - zakochana w Ottokarze, synu swej guwernantki Mirabelli. Niezadowolona więc z perspektywy ślubu z narzuconym jej kandydatem, Arsena oświadcza, że odda rękę jedynie hrabiemu lub baronowi. Barinkay czuje się odrzucony i podąża w kierunku obozu cygańskiego, by wśród Cyganów odnaleźć prawdziwych przyjaciół. Cyganie pamiętają bowiem, że ojciec Barinkaya, wbrew wszystkim, zawsze im sprzyjał i teraz odwdzięczają się, goszcząc jego syna. Ogłaszają go wręcz swoim przywódcą, nazywając „,baronem”. Ujęty postawą Cyganów Barinkay postanawia na dobre do nich przystać i wiąże się z piękną cygańską dziewczyną Saffi. Jej matka Czipra to poważana przez bandę stara i mądra Cyganka. Natchniona proroczym snem podpowiada ona, gdzie ukryty jest skarb, zakopany jeszcze za czasów tureckiej okupacji. Ale w międzyczasie przybywa hrabia Homonay z zamiarem zwerbowania mężczyzn do armii i rekwiruje odnaleziony skarb na potrzeby wojska. Konfiskata skarbu wydaje się oczywista, gdyż - jak potwierdzają historycy - „wojna o sukcesję pochłaniała ogrom środków finansowych" ${ }^{\prime}$. Ale przede wszystkim, ku zaskoczeniu wszystkich, okazuje się, że Saffi - świeżo poślubiona małżonka Barinkaya - nie jest wcale Cyganką, ale prawdziwą księżniczką. W tej sytuacji Barinkay czuje, że musi zasłużyć na miano jej męża. Wraz z innymi mężczyznami zaciąga się do wojska i wszyscy wyruszają na wojnę. Po zwycięskiej kampanii wracają do Wiednia, by tam spotkać się z ukochanymi i wspólnie świętować zwy-

9 R.W. Kowalczyk, Polityka fiskalna i gospodarcza Józefa II, „Studia z historii społeczno-gospodarczej" 2011, vol. 9, s. 7. 
among the Gypsies, and ends in a dancing Vienna under the rule of Maria There$\mathrm{sa}^{10}$. This work thus fully exploits the potential of showing on the stage the combination of baroque glamor of the era and Gypsy surroundings ${ }^{11}$. Especially the final act not only shows the charm of Vienna at the time of Maria Theresa, but can be considered a specific symbol of the epoch. The way that all the heroes from the distant province go to the glorious capital illustrates the situation of the entire monarchy, its development towards prosperity. Not only generous Maria Teresa forgives the Barinkaya family's offenses but also ennobles him (which makes him feel worthy of his wife). In fact, all the heroes, and even all the inhabitants of the Empire, can feel the closeness of the Viennese court, its caring and enjoy the rich and peaceful life provided by the queen ${ }^{12}$.

\section{The Gypsy Baron: A history of a conflict in times of wars}

$20^{\text {th }}$-century Hungarian cultural historian Péter Hanák rightly noted that the the story told in the Gypsy Baron is spiced up by the fact that many of its elements are

${ }^{10} \mathrm{~J}$. Wechsberg, The waltz emperors: the life and times and music of the Strauss family, New York 1973, p. 225.

11 E. Gartenberg, Vienna; its musical heritage, Pennsylvania 1968, p. 165.

12 A. Mayer, R. Steblin, Johann Strauss: a nineteenth century pop-idol, Wien 1999, p. 193. cięstwo oraz jasno rysującą się przyszłość pod protektoratem Marii Teresy.

Tak w skrócie można streścić akcję operetki, która zaczyna się wśród Cyganów, a kończy w roztańczonym Wiedniu pod rządami Marii Teresy ${ }^{10}$. Dzieło to w pełni zatem wykorzystuje potencjał ukazania na scenie kombinacji przepychu barokowej ery i cygańskiego otoczenia ${ }^{11}$. Zwłaszcza akt finałowy nie tylko ukazuje urok Wiednia czasów Marii Teresy, ale może być uznany za swoisty symbol epoki. Droga, jaką pokonują wszyscy bohaterowie z odległej prowincji do wspaniałej stolicy, ilustruje bowiem sytuację całej monarchii, jej rozwoju w kierunku prosperity. Nie tylko wspaniałomyślna Maria Teresa przebacza przewinienia rodziny Barinkaya, ale także nobilituje go (co sprawia, że czuje się on godzien swojej żony). W zasadzie wszyscy bohaterowie - a nawet wszyscy mieszkańcy Imperium - mogą odczuć bliskość wiedeńskiego dworu, jego opiekuńczość i cieszyć się dostatnim i spokojnym życiem zapewnionym przez królową ${ }^{12}$.

\section{Baron cygański: historia konfliktu w okresie wojen}

XX-wieczny węgierski historyk kultury Péter Hanák trafnie zauważył, że pikanterii historii opowiedzianej w Baronie cygańskim dodaje to, że wiele jej elementów jest

${ }^{10} \mathrm{~J}$. Wechsberg, The waltz emperors: the life and times and music of the Strauss family, New York 1973, s. 225.

${ }^{11}$ E. Gartenberg, Vienna; its musical heritage, Pennsylvania 1968, s. 165.

12 A. Mayer, R. Steblin, Johann Strauss: a nineteenth century pop-idol, Wien 1999, s. 193. 
taken from real events ${ }^{13}$. There are stories that have historic significance in the operetta. Wars mentioned or shown during the operetta action have a lasting effect on the heroes. Firstly, the presence of the Turks in South-European territories, as well as attempts to conquer central Europe by the Ottoman Empire, are the fate of the protagonists. We learn that Barinkaya's life in exile was the result of the expulsion of his relatives from his family estate as a punishment for his father's collaboration with the enemy. It should be added that in the times of Ottoman domination this type of wandering, especially in the Balkans, was not uncommon. Another catalyst of the history of the operetta is the Venetian-Turkish war of 1714-1718. Although it took place about twenty years before the start of the Gypsy Baron's action, events related to it conditioned the development of the stage events. During the siege of Belgrade (1717), the governess Mirabella lost her husband, who orphaned the little son Ottokar. When Mirabella talks about these past tragic facts, the operetta music layer a percussion section of orchestra sounds stylized on the sound of the Turkish music. But, as it turns out, Mirabell's husband was not killed at all on the battlefield, and many years later Count Carnero coming to Zerupán's estate is recognized as an allegedly lost husband, and Ottokar's father. Hence the old war clearly influences on the fate of the heroes. However, the pretext to show the colorful tradition of conscription to the Austrian army is the recruitment of

13 P. Hanák, The Garden and the Workshop: Essays on the Cultural History of Vienna and Budapest, Princeton 1999, p. 138. zaczerpniętych z prawdziwych wydarzeń ${ }^{13}$. W operetce pojawiają się wątki mające umocowanie historyczne. Wojny wspominane lub ukazane w trakcie akcji operetki wywierają trwały ślad na bohaterach. Po pierwsze, obecność Turków na terenach południowo-europejskich, a także próby podbicia Europy środkowej przez Imperium otomańskie warunkują losy protagonistów. Dowiadujemy się przecież, że tułacze życie Barinkaya było wynikiem wypędzenia jego bliskich z rodzinnego majątku, jako kara za to, że jego ojciec dopuścił się kolaboracji z wrogiem. Dodać należy, że w czasach otomańskiej dominacji tego rodzaju wędrówki, szczególnie w regionie Bałkanów, nie były wcale rzadkością. Kolejnym katalizatorem dziejów ukazanych w operetce jest wojna wenecko-turecka $z$ lat 1714-1718. Chociaż rozegrała się ona około 20 lat przed rozpoczęciem akcji Barona cygańskiego, to jednak wydarzenia związane z nią warunkują rozwój wydarzeń scenicznych. Podczas oblężenia Belgradu (1717) guwernantka Mirabella straciła bowiem swego męża, który osierocił maleńkiego synka Ottokara. Kiedy Mirabella opowiada o owych dawnych, tragicznych dla niej wydarzeniach, w warstwie muzycznej operetki pobrzmiewa perkusja stylizowana na brzmienie kapel janczarskich. Jednak, jak się okazuje, mąż Mirabelli wcale nie poległ na polu walki i przybywający wiele lat później do majątku Zsupána hrabia Carnero zostaje rozpoznany jako rzekomo utracony mąż oraz ojciec Ottokara. A zatem stara wojna wyraźnie odznacza się na losach

13 P. Hanák, The Garden and the Workshop: Essays on the Cultural History of Vienna and Budapest, Princeton 1999, s. 138. 
soldiers for the Austrian Succession (17401748). This war, as it is known, was on many fronts, as highlighted in the operetta: in Act Two we learn that France, Italy, Spain and Bavaria undermine the Queen's rights $^{14}$. Heroes are incorporated into the army to fight against the Spaniards, determined to take control of northern Italy. Barinkaya's friend, Count Peter Homonay, arrives with the hussar to recruit. In the finale of act two, there is a recruitment scene: Homonay sings a song encouraging joining the army, and the Gypsy presence can easily be explained by the tradition of hiring Gypsy bands that were playing in the Empire during the recruitment.

The War of the Austrian Succession served as a background not only in the Gypsy Baron, but also earlier, because in 1862 they were immortalized in the opera by Giuseppe Verdi (libretto: Francesco Maria Piave) - The force of destiny [L a forza del destino]. The action was set in the mid- $18^{\text {th }}$ century in Spain. The fate of Don Alvaro (and his comrade Don Carlos) taking part in the Battle of Velletri of 12 August 1744, is shown in it. On the other hand, German composer, Richard Strauss portrayed the charm of Vienna during the reign of $\mathrm{Ma}$ ria Theresa in his comic opera to the libretto by Hugo von Hofmannsthal The Knight of the Rose [Der Rosenkavalier] of 1911.

14 G. Jellinek, History Through the Opera Glass: From the Rise of Caesar to the Fall of Napoleon, New York 1994, p. 256. bohaterów. Jednak pretekstem do pokazania na scenie barwnej tradycji werbunku do armii austriackiej jest rekrutacja żołnierzy na potrzeby wojny o sukcesję austriacką (1740-1748). Wojna ta, jak wiadomo, toczyła się na wielu frontach, co podkreślone zostaje $w$ operetce: $w$ akcie drugim dowiadujemy się, że Francja, Włochy, Hiszpania i Bawaria podważają prawa królowej ${ }^{14}$. Bohaterowie zostają wcieleni do armii, by walczyć przeciwko Hiszpanom, zdeterminowanym, by przejąć kontrolę nad terenami północnych Włoch. Akcję rekrutacji przeprowadza przybywający z husarią przyjaciel Barinkaya - hrabia Peter Homonay. W finale aktu drugiego pokazana jest scena werbunku: Homonay śpiewa pieśń zachęcającą do wstąpienia do armii, a obecność Cyganów łatwo można wytłumaczyć kultywowaną w Imperium tradycją wynajmowania kapel cygańskich, które przygrywały podczas werbunku.

Czasy wojny o sukcesję austriacką posłużyły jako tło nie tylko w Baronie cygańskim, ale już wcześniej, gdyż w 1862 r. zostały uwiecznione w operze Giuseppe Verdiego (libretto: Francesco Marii Piave) - Moc przeznaczenia [La forza del destino]. Akcja została osadzona w połowie XVIII w. w Hiszpanii. Ukazano losy Don Alvaro (oraz jego towarzysza Don Carla) biorących m.in udział w bitwie pod Velletri 12 sierpnia $1744 \mathrm{r}$. Natomiast już sam urok Wiednia za panowania Marii Teresy uchwycił w swej operze komicznej do libretta Hugona von Hofmannsthala Kawaler srebrnej róży [Der Rosenkavalier] z $1911 \mathrm{r}$. kompozytor niemiecki, Richard Strauss.

${ }^{14}$ G. Jellinek, History Through the Opera Glass: From the Rise of Caesar to the Fall of Napoleon, New York 1994, s. 256. 


\section{Gypsy Baron: fate of the Gypsies in the Age of Enlightenment reforms}

At the symbolic level, the Gypsy Baron refers to the government of Maria Theresa in an allusive way pointing to several directions of her numerous reforms. First and foremost, though in an indirect way, the operetta refers to the eighteenth-century attempts to fight prejudices and superstitions. As it is known, in the days of Maria Theresa it was Gypsies who were considered wild and untamed. Some even think that the Gypsies were then a group connecting the Ottoman and Habsburg worlds ${ }^{15}$. And as you know, Maria Teresa, acting with the spirit of enlightenment, tried with numerous edicts to 'civilize' the Gypsies, ordering them, among other things, sedentary lifestyle. But the queen was equally active in the fight against vampire faith, etc. Thus, making the Gypsies one of the main heroes, the Gypsy Baron clearly referred to Maria Theresa's legacy, which was underlined by the introduction of mysterious themes of prophetic dreams or hidden treasure.

In the operetta, the Gypsies are initially portrayed as pariahs living off the beaten track, but with the development of the action they turn out to be trustworthy people. It is through their better understanding that non-Gypsy protagonists are convinced of them, understanding that knowledge is the key to understanding another culture. Moreover, Gypsies are join-

15 W. O'Reilly, Conceptualizing America in Early Modern Central Europe, "Pennsylvania History: A Journal of Mid-Atlantic Studies" 1998, Vol. 65, p. 105 (Explorations in Early American Culture).

\section{Baron cygański: losy Cyganów w czasach} reform oświeceniowych

Na poziomie symbolicznym Baron cygański nawiązuje do rządów Marii Teresy, aluzyjnie wskazując na kilka kierunków jej licznych reform. Przede wszystkim, chociaż w niebezpośredni sposób, w operetce odwołano się do XVIII-wiecznych prób walk z przesądami i zabobonami. Jak wiadomo bowiem, za czasów Marii Teresy to właśnie Cyganie uważani byli za dzikich i nieujarzmionych. Niektórzy nawet uważają, że stanowili oni wówczas grupę łączącą świat otomański $z$ habsburskim ${ }^{15}$. I jak wiadomo, Maria Teresa - działając $\mathrm{z}$ duchem oświeceniowym - licznymi edyktami starała się „cywilizowac" Cyganów, nakazując im m.in. osiadły tryb życia. Ale królowa równie aktywnie przyczyniała się do walki $\mathrm{z}$ wiarą $\mathrm{w}$ wampiry itp. A zatem czyniąc z Cyganów jednych z głównych bohaterów, Baron cygański wyraźnie nawiązywał do spuścizny Marii Teresy, co zostało podkreślone wprowadzeniem tajemniczych wątków dotyczących proroczych snów czy ukrytego skarbu.

W operetce Cyganie początkowo portretowani są jako pariasi żyjący na ubo$\mathrm{czu}$, ale wraz z rozwojem akcji okazują się godnymi zaufania ludźmi. To poprzez lepsze ich poznanie nie-cygańscy protagoniści przekonują się do nich, niejako rozumiejąc, że wiedza stanowi klucz do zrozumienia innej kultury. Co więcej, Cyganie na równi z innymi wstępują do ar-

15 W. O'Reilly, Conceptualizing America in Early Modern Central Europe, „Pennsylvania History: A Journal of Mid-Atlantic Studies" 1998, Vol. 65, s. 105 (Explorations in Early American Culture). 
ing the army, successfully contributing to the ultimate success of the entire forces ${ }^{16}$.

The multicolored crowd of Gypsies displayed on the musical theater floor undoubtedly puts Strauss' work in line with the tradition of the Offenbach operetta, where the role of a collective hero from the distant mysterious world was usually played by pirates, possibly vagrants or smugglers ${ }^{17}$. Such positioning of Gypsy characters resulted in a certain schematization of their portrayal, but on the background of Gypsies stereotypically shown in the discussed operetta, two female characters are particularly distinguished. This is Saffi and Chipra - an older Gypsy who is respected both by her compatriots and by not-Gypsies, in many Gypsy groups called "gody pchuri gaj". She was obeyed widely and, as Jerzy Ficowski writes, she was also often a

divination teacher, and sometimes also a fastidious expert in herbal medicine. This institution of Gypsy matron holds the eternal magical and healing traditions, maintains their continuity within the camp or the tribe, within an autonomous social unit ${ }^{18}$.

And also Chipra is able to predict the future by reading from the cards. Because of her prophetic dreams and collusions with secret powers, she also suggests where to look for a hidden treasure. As if Chipra's opposite is delicate and innocent Saffi, who New York quite stereotypically - turns out

\footnotetext{
16 V. Klotz, Operette: Porträt und Handbuch einer unerhörten Kunst, Kassel 2004, p. 39.

17 Ibidem, p. 45. p. 15.

18 J. Ficowski, Cyganie polscy, Warszawa 1953,
}

mii, walecznie przyczyniając się do ostatecznego sukcesu całego wojska ${ }^{16}$.

Wielobarwny tłum Cyganów ukazany na deskach teatru muzycznego niewątpliwie wpisywał dzieło Straussa w tradycję operetki offenbachowskiej, gdzie rolę zbiorowego bohatera pochodzącego z odległego, tajemniczego świata zazwyczaj odgrywali piraci, ewentualnie wagabundzi lub przemytnicy ${ }^{17}$. Takie usytuowanie postaci cygańskich skutkowało pewnym schematyzmem ich sportretowania, ale na tle stereotypowo ukazanych w omawianej operetce Cyganów dwie postaci kobiece szczególnie się wyróżniają. Jest to Saffi oraz Czipra - starsza Cyganka szanowana zarówno przez swoich pobratymców, jak i przez nie-Cyganów, w wielu grupach cygańskich zwana „gody pchuri daj”. Cieszyła się ona wielkim posłuchem i, jak pisze Jerzy Ficowski, często była także

nauczycielką wróżbiarstwa, a niekiedy także znachorką biegłą w dziedzinie ziołolecznictwa. Owa instytucja cygańskich matron przechowuje odwieczne tradycje magiczne i lecznicze, utrzymuje ich ciągłość w obrębie taboru czy rodu, w obrębie autonomicznej jednostki społecznej ${ }^{18}$.

Także i Czipra potrafi przepowiadać przyszłość, czytając z kart. Za sprawą jej proroczych snów i konszachtów z tajemnymi mocami podpowiada też, gdzie należy szukać ukrytego skarbu. Jakby przeciwieństwem Czipry jest delikatna i niewinna Saffi, która - dość stereotypowo - okazuje się

\footnotetext{
16 V. Klotz, Operette: Porträt und Handbuch einer unerhörten Kunst, Kassel 2004, s. 39.

17 Ibidem, s. 45

18 J. Ficowski, Cyganie polscy, Warszawa 1953, s. 15 .
} 
to be only the adopted daughter of Chipra, not Gypsy by birth.

To justify the transformation of Saffi's fate, the creators of the operetta carefully introduced a song in which a girl, still convinced that she herself is a Gypsy, shares the superstitions that most often associates with the Gypsies ${ }^{19}$. In the aria of the first act 'So elend und so true', we learn that Gypsies are potential thieves, unfaithful lovers ${ }^{20}$. The motif of Gypsy love, "just on the stage of the musical theater, reached the fullest realization, was allegorized"21, but in the Gypsy Baron this thread was very stereotyped, because it is the Gypsy who has "loose moral and sexual norms" there ${ }^{22}$. According to Camille Crittenden, such portraying the Gypsies as people unsatisfied and sexually assaulted, in the nineteenth-century Vienna served the need to indulge in voyeuristic pleasures resulting from peeping and at the same time while preserving a sense of their own ethical superiority ${ }^{23}$. This thesis is well-illustrated by the juxtaposition of two rendezvous of the non-Gypsy and Gypsy pairs shown in the operetta. While for the first, i.e. Arsenie and Ottokar, it is suffice to have a secret, romantic evening meeting, the allegedly Gypsy lovers Saffi and Barin-

19 C. Crittenden, op. cit., p. 187.

20 On the sources of such a stereotype see: I. Hancock, Introduction, [in:] Gypsies of Eastern Europe, edit. D. Crowe, J. Kolsti, Armonk 1991, p. 5.

21 A.G. Piotrowska, Miłość cygańska w muzyce - kreacja artystyczna czy poszukiwania wzoru idealnego?, [in:] Romowie w Polsce i w Europie. Od dyskryminacji do tolerancji, edit. A. Bartosz, P. Borek, B. Gryszkiewicz, Kraków 2015, p. 75.

22 C. Crittenden, op. cit., p. 182 ("looser moral or sexual codes").

23 Ibidem, p. 187. jedynie przybraną córką Czipry, a nie Cyganką z urodzenia.

Dla uzasadnienia przemiany losów Saffi, twórcy operetki przezornie wprowadzili pieśń, w której dziewczyna - wciąż przekonana, że sama jest Cyganką - wymienia najczęściej kojarzone z Cyganami przesądy $^{19}$. W arii z pierwszego aktu So elend und so true dowiadujemy się więc, że Cyganie to potencjalni złodzieje, niewierni kochankowie ${ }^{20}$. Motyw miłości cygańskiej „właśnie na deskach teatru muzycznego, doczekał się najpełniejszej realizacji, został wręcz alegoryzowany"21, ale w Baronie cygańskim wątek ten poprowadzony został bardzo stereotypowo, gdyż to właśnie Cyganie mają tam „luźne moralne i seksualne normy"22. A zdaniem Camille Crittenden takie ukazanie Cyganów - jako ludzi nienasyconych i rozpasanych seksualnie - służyło w XIX-wiecznym Wiedniu potrzebie zaspokojenia wojerystycznych przyjemności wynikających z podglądania, przy jednoczesnym zachowaniu poczucia własnej wyższości etycz$n^{2 j^{23}}$. Doskonale tezę tę ilustruje zestawienie dwóch, ukazanych w operetce, randek młodych par: nie-cygańskiej i cygańskiej. O ile tej pierwszej, tj. Arsenie i Ottokarowi, wystarcza ukradkowe, romantycz-

19 C. Crittenden, op. cit., s. 187.

20 O źródłach takiego stereotypu, zob. I. Hancock, Introduction, [w:] Gypsies of Eastern Europe, red. D. Crowe, J. Kolsti, Armonk 1991, s. 5.

21 A.G. Piotrowska, Miłość cygańska w muzyce - kreacja artystyczna czy poszukiwania wzoru idealnego?, [w:] Romowie w Polsce i w Europie. Od dyskryminacji do tolerancji, red. A. Bartosz, P. Borek, B. Gryszkiewicz, Kraków 2015, s. 75.

22 C. Crittenden, op. cit., s. 182 („looser moral or sexual codes").

23 Ibidem, s. 187. 
kay succumb to lust and spend a dreamy night despite a brief period of acquaintance. Moreover, the girl's mother, Chipra, accepts such fast consumption of the relationship. Saffi and Barinkaya's relationship in Vienna in the nineteenth century Vienna was judged as unsuitable, and the censor at the time clearly stated that the link between them could not even be called 'wild', but merely defined as an illegally married couple ${ }^{24}$. In other Strauss's operettas you can read many references to the double moral norms of the Habsburg rule, among others, in the famous Revenge of the Bat (Die Fledermaus) of 1874, where the maid Adela sings about herself as a modest girl, but to be married. Perhaps it is another reference to the time of Maria Theresa, when a special committee on the purity of morals and education (Keuschheitskommission) was established.

Spending a sleepless night with Saffi, Barringay, who is allegedly a Gypsy baron, in his song 'Als Flotter Geist' from the first act, referrs to the stereotypical portrayal of the Gypsies, telling of his adventures as an acrobat or tamer of wild animals. This story brings to mind the typical images of gypsies engaged in activities of strolling players, and their famous skills in taming wild animals. Such a perception of the Gypsies was firmly rooted in Central and Eastern Europe. Jerzy Ficowski states that as early as in 1575 the papal nuncio Lippomano reported on the trained bear

24 W. Jaspert, Johann Strauss. Sein Leben, sein Werk, seine Zeit, Berlin 1939, p. 193 ("das Verhältnis des Paares Barinkay-Saffi durfte im Text nicht als 'wilde Ehe' bezeichnet werden, sondern musste in eine 'unerlaubte Ehe' umgewandelt werden"). ne spotkanie wieczorową porą, o tyle rzekomo cygańscy kochankowie - Saffi i Barinkay - poddają się żądzom i spędzają ze sobą upojną noc, pomimo krótkiego okresu znajomości. Co więcej, matka dziewczyny Czipra pochwala taką szybką konsumpcję związku. Relację Saffi i Barinkaya w XIX-wiecznym Wiedniu oceniano jako nieodpowiednią i ówczesny cenzor wyraźnie zaznaczył, że łączące ich więzy nie można nawet nazwać „dzikimi”, a jedynie określić jako nielegalnie zawarte małżeństwo $^{24}$. W innych operetkach Straussa niejednokrotnie odczytać można nawiązania do podwójnych standardów moralnych obowiązujących za panowania Habsburgów, m.in. w słynnej Zemście nietoperza (Die Fledermaus) z 1874 r., gdzie pokojówka Adela śpiewa o sobie jako dziewczęciu skromnym, lecz do wzięcia. Być może jest to kolejne nawiązanie do czasów Marii Teresy, kiedy to powołano do życia specjalną komisję do spraw czystości obyczajów i wychowania (Keuschheitskommission).

Spędzający upojną noc z Saffi, jej nielegalnie poślubiony małżonek - Barinkay, będący rzekomym baronem cygańskim, w swej pieśni Als flotter Geist z aktu pierwszego nawiązuje do stereotypowego portretowania Cyganów, opowiadając o swoich przygodach jako akrobaty czy tresera dzikich zwierząt. Opowieść ta przywodzi na myśl typowe wyobrażenia o Cyganach parających się zajęciami związanymi z występami w wędrownych trupach, tudzież

24 W. Jaspert, Johann Strauss. Sein Leben, sein Werk, seine Zeit, Berlin 1939, s. 193 („das Verhältnis des Paares Barinkay-Saffi durfte im Text nicht als 'wilde Ehe' bezeichnet werden, sondern musste in eine 'unerlaubte Ehe' umgewandelt werden"). 
known in Lithuania, and "the bear tamers were probably Gypsies" 25 . Training bears was common among gypsies "in ancient times, when there were a lot of bears in our forests, [...]. With time, due to the rapid disappearance of bears in our forests, the bear only the rich Gypsies or newcomers from the Balkans, the Ursari clan could tame bears" ${ }^{\prime 26}$. But even in the early nineteenth century, Iganacy Daniłowicz recalled that "training the monkeys in Italy, and the bears in Lithuania fed more than one family"27.

What is symptomatic, and featured in the title of the operetta, Barinkay is hailed as a Gypsy baron, even though he is not the Gypsy himself, but only the son of the fallen-in-disgrace landowner. So Barinkay is not so much a 'Gypsy baron' as the 'baron' of the Gypsies. The association of the Gypsies with their own social system, their own jurisdiction and sovereignty is a clear reference in the operetta to another, long-standing Gypsy tradition. As Jerzy Ficowski wrote: "At the head of each caravan there is an elderly Gypsy who sets the direction of the hike, the place of stay, the dates of departure. In the Kalderars, the hierarchy of these chiefs is more diversified: the village heads are governed by the mayors and the mayors are subordinate to the 'king ${ }^{28}$.

Ficowski also mentioned Gypsy barons, but he had not found such a case from the Polish territory until 1935. At that time

25 J. Ficowski, op. cit., p. 76.

26 Ibidem.

27 I. Daniłowicz, O Cyganach wiadomość historyczna, Wilno 1824 , p. 42.

28 J. Ficowski, op. cit., p. 66. ich słynnymi umiejętnościami poskramiania dzikich zwierząt. Takie postrzeganie Cyganów było mocno zakorzenione w Europie środkowej i wschodniej: Jerzy Ficowski podaje, że już w 1575 r. nuncjusz papieski Lippomano donosił o tresowanych niedźwiedziach znanych na Litwie, a „ówcześni niedźwiednicy byli przypuszczalnie Cyganami”"25. Tresura niedźwiedzi była wśród Cyganów powszechna „w dawnych wiekach, kiedy niedźwiedzi po naszych borach było pełno, [...]. Z czasem, wskutek szybkiego zanikania niedźwiedzi w naszych lasach, niedźwiednictwem trudnić się mogli już tylko Cyganie bogatsi lub nowi przybysze z Bałkanów, klan Ursari"26. Ale jeszcze na początku XIX w. Iganacy Daniłowicz wspominał, że „wodzenie małp we Włoszech, a niedźwiedzi w Litwie, nie jedną familiją wyżywiła"27.

Co symptomatyczne, i uwypuklone w samym tytule operetki, Barinkay zostaje okrzyknięty baronem cygańskim, mimo że przecież sam Cyganem nie jest, a jedynie synem popadłego w niełaskę właściciela ziemskiego. A zatem Barinkay jest nie tyle „cygańskim baronem», ile „baronem» Cyganów. Kojarzenie Cyganów z ich własnym systemem społecznym, własną jurysdykcją i zwierzchnictwem, to wyraźne odwołanie się w operetce do kolejnej, długoletniej tradycji cygańskiej. Jak bowiem pisał Jerzy Ficowski: „na czele każdego taboru stoi starszy Cygan, który ustala kierunki wędrówek, miejsca pobytu, terminy

\footnotetext{
25 J. Ficowski, op. cit., s. 76.

26 Ibidem.

27 I. Daniłowicz, O Cyganach wiadomość historyczna, Wilno 1824, s. 42.
} 
came the self-styled head of the Gypsies Matejasz Kwiek appeared, calling himself the 'baron'29.

The relations between Gypsies and non-Gypsies appear in the operetta according to a rather stereotypical pattern. Although the focus was on emphasizing on community of interests under the patronage of the monarch, some common prejudices against the Gypsies were also suggested. The initial relationships between the Gypsies and non-Gypsies are antagonistic: Barinkay, rejected by Arsena and her family, is ridiculed as the socalled Gypsy baron. When in retaliation for such despicable treatment he decides to humiliate Arsena, publicly declares that instead of her he chooses... Saffi, the Gypsy. This step is read as an unambiguous act of negligence, even insulting the respected family. In such a situation, the marriage between Barinkay, a Gypsy Baron and Arsena as a non-Gypsy, can not be entered: not so much out of the operetta convention as because of the socially acceptable norm ${ }^{30}$. But with the development of the action, the Gypsies, initially not very well portrayed, are increasingly attracting the audience. Ultimately, they turn out to be noble and trustworthy people, finding their place in the structures of the multiethnic monarchy.

In spite of the finally positive image of the Gypsies, in the Strauss's operetta, however, the more serious reforms of Maria Theresa resonate: not only educational ${ }^{31}$

29 Ibidem.

30 See: C. Crittenden, op. cit., p. 187.

31 Among other things, Maria Teresa introduced a compulsory schooling in 1774 . See: A. Kunce, ruszania w drogę. U Kalderarów hierarchia tych naczelników jest bardziej zróżnicowana: są sołtysi, podlegający wójtom i wójtowie podlegli »królowi«"28.

Ficowski wspominał także o baronach cygańskich, ale odnotował taki przypadek z terenów Polski dopiero w 1935 r. Wówczas to pojawił się bowiem samozwańczy zwierzchnik Cyganów Matejasz Kwiek, sam siebie nazywający „baronem”29.

Ukazane w operetce relacje pomiędzy Cyganami i nie-Cyganami układają się według dość stereotypowego wzorca. Chociaż główny nacisk położono na zaakcentowanie wspólnoty interesów pod protektoratem monarchini, jednak zasugerowano także kilka typowych uprzedzeń, jakie żywiono wobec Cyganów. Początkowe relacje pomiędzy Cyganami i nie-Cyganami kształtują się antagonistycznie: Barinkay, odrzucony przez Arsenę i jej rodzinę, zostaje wyśmiany jako tzw. cygański baron. Kiedy w odwecie za tak nikczemne potraktowanie postanawia on poniżyć Arsenę, publicznie oświadcza, że zamiast niej wybiera... Cygankę Saffi. Krok ten odczytany zostaje jako jednoznaczny akt lekceważenia, wręcz znieważenia szanowanej rodziny. W takiej sytuacji małżeństwo pomiędzy Barinkayem będącym cygańskim baronem a Arseną jako nie-Cyganką nie może dojść do skutku: nie tyle nie mieszcząc się w ramach konwencji operetkowej, ile społecznie akceptowanej normy ${ }^{30}$. Ale wraz z rozwojem akcji Cyganie - początkowo niezbyt przychylnie portretowani zaskarbiają sobie coraz większą sympatię

\footnotetext{
28 J. Ficowski, op. cit., s. 66.

29 Ibidem.

30 Por. C. Crittenden, op. cit., s. 187.
} 
but also those aimed at turning "subject into citizens"32. This was achieved, inter alia, by the incorporation of the Gypsies into the social fabric of the Empire, at the expense of their cultural identity. The efforts of Maria Theresa (and later also her son Joseph II) were aimed at forcing the Gypsies to lead a sedentary lifestyle, and sometimes the Gypsy children were being taken from their parents. Maria Teresa considered the reforms, which were the cause of many misfortunes, necessary and was tirelessly putting into practice ${ }^{33}$, and the empress's motto was the action "strong in action, gentle in the mode" (foriter in re, suaviter in modo $)^{34}$. However, in spite of her efforts to make Gypsies law-abiding citizens of the monarchy, the term 'Gypsy' continued to evoke negative associations, as clearly shown in the operetta. At the same time, it should be emphasized that it was from the second half, and especially at the end of the $18^{\text {th }}$ century, that studies of the culture or language of the Gypsies were increasingly being undertaken. They tried to explain the mystery of their origin and behavior, as other numerous phenomena were explained at that time, so far considered to be associated with secret and even impure powers. It is well known that Maria Teresa, considered to be an orthodox Catholic, had to deal with the waves of gos-

Ślask, masa i XIX wiek, "Anthropos" 2014, vol. 22, p. 57.

${ }^{32}$ M. Małecki, Ideologiczne podstawy reform terezjańsko-józefińskich, [in:] Krakowskie studia z historii państwa i prawa, edit. W. Uruszczak, D. Malec, M. Mikuła, vol. 3, Kraków 2010, p. 115.

${ }^{33} \mathrm{~K}$. Bercovici, The story of the Gypsies, New York 1928, p. 91.

34 M. Małecki, op. cit., p. 115. widzów. Ostatecznie okazują się ludźmi szlachetnymi i godnymi zaufania, odnajdując swoje miejsce w strukturach wieloetnicznej monarchii.

Pomimo pozytywnego, w ostatecznym rozrachunku, obrazu Cyganów, w operetce Straussa pobrzmiewają jednak wspomnienia bardziej surowych reform Marii Teresy: nie tylko edukacyjnych ${ }^{31}$, ale także i tych zmierzających do uczynienia $\mathrm{z}$,poddanych obywateli”32. Działo się tak m.in. za sprawą wcielania Cyganów do tkanki społecznej Imperium, kosztem ich tożsamości kulturowej. Wysiłki Marii Teresy (a potem także jej syna Józefa II) nakierunkowane były na zmuszenie Cyganów do prowadzenia osiadłego trybu życia, czasami też cygańskie dzieci odbierano rodzicom. Będące powodem wielu nieszczęść reformy Maria Teresa uważała za konieczność i niestrudzenie wcielała w życie ${ }^{33}$, a „maksymą cesarzowej było działanie «twarde w materii, łagodne w sposobie» (foriter in re, suaviter in modo)" 34 . Jednak pomimo jej wysiłków, by z Cyganów uczynić praworządnych obywateli monarchii, samo określenie "Cygan” nadal budziło negatywne skojarzenia, co wyraźnie pokazano w operetce. Jednocześnie należy podkreślić, że to właśnie od drugiej połowy, a zwłaszcza pod koniec XVIII w., coraz częściej podejmowano badania nad kulturą czy językiem

31 M.in. Maria Teresa wprowadziła w 1774 r. obowiązek szkolny. Por. A. Kunce, Śląsk, masa i XIX wiek, „Anthropos” 2014, vol. 22, s. 57.

32 M. Małecki, Ideologiczne podstawy reform terezjańsko-józefińskich, [w:] Krakowskie studia $z$ historii państwa i prawa, red. W. Uruszczak, D. Malec, M. Mikuła, t. 3, Kraków 2010, s. 115.

$33 \mathrm{~K}$. Bercovici, The story of the Gypsies, New York 1928, s. 91.

34 M. Małecki, op. cit., s. 115. 
sip about vampires that prowled the eastern outskirts of her Empire. The personal physician of the monarch, Gerard van Swieten, examined the phenomenon ${ }^{35}$ so that, finally, in the report of the Abhandlung des Daseyns der Gespenster (1768) he would announce a scientific explanation of the phenomena considered inexplicable. In order to avoid panic, Maria Teresa published edicts forbidding the exhumation of corpses and their desecration ${ }^{36}$. Her efforts to eradicate prejudices and faith in superstition were cleverly, though not explicitly, incorporated into the content of the Gypsy Baron operetta: the supposedly supernatural abilities of Czipra showing the place of treasure hiding can easily be explained by her memory of past times, especially considering her old age.

\section{Gypsy Baron: Saffi's life under the rule of Maria Theresa}

When the story of the Gypsy Baron begins, Maria Teresa, twenty-one years old, is at the beginning of her reign. Although her father, Charles VI, attempted to ensure her succession to the Habsburg throne, that right was questioned. Austria was in a state of war, which was not facilitated by

35 D. Hall, R. Hellman, Vampire Legends and Myths, New York 2012, p. 105.

36 D. Bailey, Vampires in Mythology, New York 2012, p. 52.
Cyganów. Starano się wyjaśnić tajemnicę ich pochodzenia i zachowania, tak jak tłumaczono wówczas wiele innych zjawisk, uważanych do tej pory za związane z siłami tajemnymi, a nawet nieczystymi. Powszechnie wiadomo, że uważana wręcz za ortodoksyjną katoliczkę Maria Teresa musiała borykać się z falami plotek na temat wampirów, jakoby grasujących na wschodnich rubieżach jej Imperium. Osobisty lekarz monarchini, Gerard van Swieten, badał ten fenomen ${ }^{35}$, by ostatecznie w raporcie Abhandlung des Daseyns der Gespenster (1768) obwieścić naukowe wyjaśnienie zjawisk uważanych za niewytłumaczalne. W celu uniknięcia paniki Maria Teresa wydała edykty zabraniające ekshumacji zwłok oraz ich bezczeszczenia ${ }^{36}$. Jej wysiłki, by wyplenić zabobony i wiarę w przesądy, sprytnie, choć nie wprost, wpleciono w treść operetki Baron cygański: rzekomo nadprzyrodzone zdolności Czipry wskazującej miejsce ukrycia skarbu można bowiem łatwo wytłumaczyć jej dobrą pamięcią minionych czasów, zwłaszcza zważywszy jej sędziwy wiek.

\section{Baron cygański: życie Saffi za rządów Marii Teresy}

Kiedy rozpoczyna się akcja Barona cygańskiego, dwudziestokilkuletnia Maria Teresa jest u progu swego panowania. Chociaż jej ojciec Karol VI usiłował zapewnić jej sukcesję tronu Habsburgów, prawo to zostało zakwestionowane. Austria znalazła się w stanie wojny, czego nie ułatwiała

35 D. Hall, R. Hellman, Vampire Legends and Myths, New York 2012, s. 105.

36 D. Bailey, Vampires in Mythology, New York 2012, s. 52. 
the internal situation of the country: catastrophic finances and an empty treasury ruined by the Turks, and a disorganized army ${ }^{37}$. Maria Teresa had to not only find a solution to these problems, but above all, to prove that her royal heritage empowered her to the imperial heritage. One of the main characters of the Strauss's operetta is in a comparable situation. This is Saffi, who is the daughter of the pasha of Temesvár and not the ordinary Gypsy. But to gain recognition in the eyes of the environment, the girl must overcome a number of adversities. The coincidence of the fate of Saffi and Maria Theresa, though not prominent in the operetta, deserves attention. The significance of Maria Theresa itself appears in the operetta not to be overestimated: in consequence, in some of today's Gypsy Baron realizations, the spoken role of the queen is introduced. She appears in the Schönbrunn Palace as a young ruler surrounded by her ministers ${ }^{38}$. It can be risked to say that both Maria Teresa and Saffi are victims of their own gender: not crowned empress of Austria, as a woman, must prove her rights, while Saffi, as a girl, can only become Barinkaya's wife, but not a full-fledged leader of the Gypsies. Hence while "the concept of control seems to be permanently inscribed in the

37 G.E. Rothenberg, The Habsburg Army in the Napoleonic Wars, "Military Affairs" Feb., 1973, Vol. 37, No. 1, p. 1.

38 In 2010, the Japanese theater group Moon presented the Gypsy Baron at the Takarazuka Grand Theater and the Tokyo Takarazuka Theater, putting on the stage the character of Maria Theresa. See: The Gypsy Baron / Rhapsodic Moon, http://www. takawiki.com/tiki-index.php?page $=$ The + Gypsy $+B$ aron $+\% 2 \mathrm{~F}+$ Rhapsodic + Moon+ $($ Moon +2010$)[\mathrm{ac}-$ cess on: 2.02.2017]. sytuacja wewnętrzna kraju: katastrofalny stan finansów i pusty skarbiec zrujnowany wojnami z Turkami oraz zdezorganizowana $\operatorname{armia}^{37}$. Maria Teresa musiała nie tylko znaleźć rozwiązanie tych problemów, ale przede wszystkim udowodnić, że jej królewskie pochodzenie uprawniało ją do imperatorskiego dziedzictwa. W nieco podobnej sytuacji znajduje się jedna z głównych bohaterek operetki Straussa. Mowa o Saffi, która jest córką paszy Temesváru, a nie zwykłą Cyganką. Jednak aby zyskać uznanie w oczach otoczenia, dziewczyna musi pokonać wiele przeciwności. Zbieżność losów Saffi i Marii Teresy, chociaż niewyeksponowana w operetce, jednak zasługuje na uwagę. Sama ranga postaci Marii Teresy wydaje się w operetce nie do przecenienia: w konsekwencji, w niektórych dzisiejszych realizacjach Barona cygańskiego wprowadza się mówioną rolę królowej. Pojawia się więc w Pałacu Schönbrunn jako młodziutka władczyni w otoczeniu swoich ministrów ${ }^{38}$. Można zaryzykować stwierdzenie, że zarówno Maria Teresa jak i Saffi są ofiarami własnej płci: niekoronowana cesarzowa austriacka, jako kobieta, musi udowodnić swoje prawa, natomiast Saffi, jako dziewczyna, może jedynie zostać żoną Barinkaya, ale nie pełnoprawną przywódczynią grupy Cyganów. O ile więc „pojęcie kontroli wydaje się permanentnie

37 G.E. Rothenberg, The Habsburg Army in the Napoleonic Wars, "Military Affairs" 1973, Vol. 37, No. 1, s. 1.

${ }^{38}$ W 2010 r. japońska grupa teatralna Moon wystawiła Barona cygańskiego w Takarazuka Grand Theatre oraz Tokyo Takarazuka Theatre, wprowadzając na scenę postać Marii Teresy. Por.: The Gypsy Baron / Rhapsodic Moon, http://www.takawiki.com/ tiki-index.php?page $=$ The + Gypsy + Baron $+\% 2 F+R h$ apsodic+Moon+(Moon+2010) [dostęp: 2.02.2017]. 
evolving identity of Maria Theresa" ${ }^{39}$, such a privilege is denied to Saffi, who is forced to surrender to the will of others, though as we know - has her own opinion. But her origins and sex determine her destiny, which also brings her character to the historic Maria Theresa.

\section{Gypsy Baron: musical document}

The Gypsy Baron is an operetta firmly rooted in Viennese music traditions: first and foremost, it is full of fighting and elements of style associated with the Hungarian Gypsies ${ }^{40}$. There are also musical references to military traditions, for example, in the final scene of the second, or in the triumphant march of the beginning of the third act. At that time, the great Austrian warfare is celebrated in Vienna, the heroes happily return from the war, couples in love reunite ${ }^{41}$. As it has already been mentioned, the Turkish allusions resound in the form of the so-called oriental determinants ${ }^{42}$ interwoven into the musical tissue of the whole work. You can hear them when Mirabella talks about the siege of Belgrade, and, as Lynn Hooker suggests, they can be found in many parts of the

39 A. Judzińska, Cesarska kobiecość monarchii naddunajskiej - w cieniu balansujacej kontroli, Studium psychospołeczne, "Studia Edukacyjne" 2015, No. 36, p. 199.

40 See: J. Bellman, Toward a Lexicon for the Style hongrois, "The Journal of Musicology" 1991, Vol. 9 , No. 2, pp. 214-237.

41 L. Hooker, Turks, Hungarians, and Gypsies on stage: exoticism and auto-exoticism in opera and operetta, "Hungarian Studies" 2013, Vol. 27, No. 2, p. 300 .

42 D.B. Scott, From the Erotic to the Demonic: On Critical Musicology, New York 2003, p. 158. wpis(yw)ane w ewoluującą tożsamość Marii Teresy"39, takiego przywileju odmawia się Saffi, która zmuszona jest do poddania się woli innych, chociaż - jak wiemy - ma swoje zdanie. Ale jej pochodzenie oraz płeć determinują jej losy, co także zbliża jej postać do historycznej Marii Teresy.

\section{Baron cygański: muzyczny dokument}

Baron cygański to operetka mocno zakorzeniona $\mathrm{w}$ wiedeńskich tradycjach muzycznych: przede wszystkim obfituje w walce oraz elementy stylu kojarzonego z węgierskimi Cyganami ${ }^{40}$. Pojawiają się w niej także muzyczne odniesienia do tradycji militarnych, np. we wspominanej scenie finałowej aktu drugiego czy w tryumfalnym marszu na rozpoczęcie aktu trzeciego. Wówczas to wielka wiktoria wojsk austriackich celebrowana jest w Wiedniu, bohaterowie szczęśliwie powracają z wojny, zakochane pary łączą się na nowo ${ }^{41}$. Jak też już wzmiankowano, tureckie aluzje pobrzmiewają w postaci tzw. orientalnych wyznaczników ${ }^{42}$ wplecionych do muzycznej tkanki całego dzieła. Słychać je, kiedy Mirabella opowiada o oblężeniu Belgradu, a także - jak sugeruje Lynn Hooker doszukać można się ich w wielu partiach

39 A. Judzińska, Cesarska kobiecość monarchii naddunajskiej - w cieniu balansujacej kontroli. Studium psychospołeczne, „Studia Edukacyjne” 2015, nr 36, s. 199.

40 Por. J. Bellman, Toward a Lexicon for the Style hongrois, „The Journal of Musicology” 1991, Vol. 9, No. 2, s. 214-237.

41 L. Hooker, Turks, Hungarians, and Gypsies on stage: exoticism and auto-exoticism in opera and operetta, „Hungarian Studies” 2013, Vol. 27, No. 2, s. 300.

42 D.B. Scott, From the Erotic to the Demonic: On Critical Musicology, New York 2003, s. 158. 
Gypsy characters ${ }^{43}$. Such simplified musical manipulation of the determinants (i.e. the combination of the Turkish and Gypsy idioms), however, corresponds quite well to the musical situation of the southern European territories, where Turkish influences, often cultivated by Gypsy bands, were clearly marked ${ }^{44}$.

\section{Gypsy Baron: reception repercussions in the twentieth century}

Taking into account the simplicity of the action, the presence of easily catching melodies and numerous references to exotic (e.g. Turkish or Gypsy) sounds, it is hardly surprising that the Gypsy Baron was an immediate success. From the day of its release at the end of the nineteenth century, the work has still been performed on the stages of musical theaters. Not only is it one of Strauss's most famous operet$\operatorname{tas}^{45}$, but perhaps one of the most recognizable operettas in Vienna at all. Hence it is not surprising that the very term 'Gypsy baron' has been firmly anchored in European culture and sometimes appears in atypical contexts. During World War II, the code name 'Zigeunerbaron' was the name of, for example, an offensive campaign carried out by six German army di-

43 L. Hooker, op. cit., p. 301.

44 M. Velimirović, Balkan music history in the seventeenth and eighteenth centuries. Introductory remarks, "Revista de Musicología" 1993, Vol. 16, No. 3, (Del XV Congreso de la Sociedad Internacional de Musicología: Culturas Musicales Del Mediterráneo y sus Ramificaciones), Vol. 3, p. 1704.

45 R. Traubner, op. cit., p. 129 ("The score of the Gypsy Baron is generally rated Strauss's number two work, directly after Die Fledermaus"). przypisanych postaciom cygańskim ${ }^{43}$. Takie uproszczone operowanie muzycznymi wyznacznikami (tj. skojarzenie idiomu tureckiego i cygańskiego) koresponduje jednak dość dobrze z ówczesną sytuacją muzyczną panującą na południowych terenach Europy, gdzie zaznaczyły się wyraźnie wpływy tureckie, kultywowane niejednokrotnie właśnie przez kapele cygańskie ${ }^{44}$.

\section{Baron cygański: reperkusje recepcji w wieku XX}

Zważywszy na prostotę akcji, tudzież obecność łatwo wpadających w ucho melodii oraz licznych odnośników do egzotycznych (np. tureckich lub cygańskich) brzmień, trudno dziwić się, że Baron cygański odniósł natychmiastowy sukces. Od dnia swej premiery pod koniec wieku XIX dzieło to wciąż jest wykonywane na deskach teatrów muzycznych. Nie tylko więc jest to jedna $z$ najbardziej znanych operetek Straussa ${ }^{45}$, ale być może także jedna $z$ najbardziej rozpoznawalnych operetek wiedeńskich w ogóle. A zatem nie dziwi to, że samookreślenie „baron cygański” mocno zakotwiczyło się w kulturze europejskiej i pojawia się niekiedy w dość nietypowych kontekstach. W czasach II wojny światowej kryptonim „Zigeunerbaron” nosiła np. akcja ofensywna przeprowadzo-

43 L. Hooker, op. cit., s. 301.

44 M. Velimirović, Balkan music history in the seventeenth and eighteenth centuries. Introductory remarks, „Revista de Musicología” 1993, Vol. 16, No. 3 (Del XV Congreso de la SociedadInternacional de Musicología: Culturas Musicales Del Mediterráneo y sus Ramificaciones), Vol. 3, s. 1704.

45 R. Traubner, op. cit., s. 129 („The score of the Gypsy Baron is generally rated Strauss's number two work, directly after Die Fledermaus"). 
visions, preparing ground for Operation Zitadelle, one of the last major campaigns on the Eastern Front ${ }^{46}$.

But above all, the Gypsy Baron is remembered as an operetta associated with the legacy of the Austro-Hungarian monarchy. It also pointed to the meaning of the work to supposed to help strengthen the sense of unity of the multinational state. However, the citizens of the monarchy themselves sometimes expressed ambiguous opinions about the message of the Gypsy Baron. Recognized composer Ernst Křenek (1900-1991) criticized the operetta, suggesting that:

The Gypsy Baron represents a bad step toward an even worse future; is the beginning of the cultural scandal of the later Vienna operetta, which dominated the beginning of the $20^{\text {th }}$ century [...]. Sentimentalism spread with the help of folkloric ignorance: it led to the recognition of the non-German speaking citizens of Austro-Hungarian monarchy as laughter worthy of exotic operetta trivia - the consequences of this custom are still felt today. And all this is a beautifully rich musical garment that will provide a certain vitality to these works, even when they themselves cease to be interesting as the relics of a certain age - wonderful, sad and very strange $e^{47}$.

${ }^{46}$ See: S. Robbins, Dirty Wars: A Century of Counterinsurgency, Stroud 2016

${ }^{47}$ E. Kř̀enek, A Few Words About Johann Strauss, [in:] E. Křenek, Exploring Music. Essays by Ernst Křenek, London 1966, pp. 21-22 ("The Gypsy Baron represents an ill-advised step into a worse future; it is the beginning of the cultural scandal of later Viennese operetta which dominated the beginning of the twentieth century [...]. Sentimentality reared its ugly head along with a distasteful folkloristic arrogance; this led to the habit of seeing the non-German speaking people of the Austrian monarchy as curious, laughable exotics, [...], of operetta - a habit whose consequences we are still suffering today. As the same, everything is wrapped up in a phenomenal wealth of beautiful music which will na przez sześć dywizji armii niemieckiej, przygotowującej grunt pod operację , $\mathrm{Zi}$ tadelle" będącą jedną z ostatnich wielkich kampanii na froncie wschodnim ${ }^{46}$.

Ale ponad wszystko Baron cygański pamiętany jest jako operetka kojarzona ze spuścizną austro-węgierskiej monarchii. Wskazuje się też na wymowę dzieła, mającą przyczynić się do wzmocnienia poczucia jedności wielonarodowego państwa. Jednak sami obywatele monarchii niekiedy wyrażali dość ambiwalentne opinie na temat przekazu Barona cygańskiego. Uznany kompozytor Ernst Křenek (1900-1991) krytycznie wyrażał się o operetce, sugerując, że:

Baron cygański reprezentuje niedobry krok w stronę jeszcze gorszej przyszłości; jest początkiem kulturalnego skandalu późniejszej operetki wiedeńskiej, która zdominowała początek XX wieku [...]. Sentymentalizm rozpanoszył się wsparty folklorystyczną ignorancją: to doprowadziło do zwyczaju uznawania nie mówiącej po niemiecku ludności monarchii Austro-węgierskiej za śmiechu warte egzotyczne ciekawostki operetkowe - konsekwencje tego zwyczaju wciąż dają się odczuć obecnie. I wszystko to przybrane przepięknie bogatą szatą muzyczną, która zapewni tym dziełom pewną żywotność, nawet wtedy kiedy one same przestaną być interesujące jako przeżytki pewnej epoki - cudownej, smutnej i bardzo dziwnej ${ }^{47}$.

${ }^{46}$ Por. S. Robbins, Dirty Wars: A Century of Counterinsurgency, Stroud 2016.

47 E. Křenek, A Few Words About Johann Strauss, [w:] E. Křenek, Exploring Music. Essays by Ernst Křenek, London 1966, s. 21-22 („The Gypsy Baron represents an ill-advised step into a worse future; it is the beginning of the cultural scandal of later Viennese operetta which dominated the beginning of the twentieth century [...]. Sentimentality reared its ugly head along with a distasteful folkloristic arrogance; this led to the habit of seeing the non-German speaking people of the Austrian mon- 
Was it really a "sad and very strange" epoch, or rather an age in which new ways of legitimizing the functioning of the multinational monarchy were sought? The musical theater proved to be a wonderful place to promote its ideals, in particular to emphasize the continuity of tradition. The years of Maria Theresa's rule were thus presented as a period of military victories and educational successes, as times of social change and general prosperity. Undoubtedly, the Gypsy Baron can be considered as the musical testimony of the epoch in which it was created, as well as the musical monument in honor of Maria Theresa.

\section{Abstract}

Considered a musical monument to the AustroHungarian Empire - The Gypsy Baron (originally Der Zigeunerbaron) of 1885 composed by Johann Strauss II (1825-1899) reveals how important position Maria Theresia had in the Empire in the long nineteenth century. It is also a great example of keeping, in Vienna at the end of the nineteenth century, hold of the memory of her politics. The Gypsy Baron is clearly the work inscribed into political situation as it constituted a specific response to a concrete need to stimulate civil attitudes (so desired within the Empire at that time). Treating the Gypsy Baron as a case study, the paper suggests that although the world of operetta might be overlooked or underestimated when discussing the role of political propaganda and the issues of collective memory. It should be recognized as one of the key sites employed to promote the Habsburgs' vision of their Empire.

always give these works a certain life even when they themselves are no longer interesting as memories of a great period - brilliant, sad and very strange").
Czy rzeczywiście była to epoka „,smutna i bardzo dziwna", czy raczej epoka, w której poszukiwano nowych sposobów uprawomocnienia funkcjonowania wielonarodowej monarchii? Teatr muzyczny okazał się miejscem doskonałym do propagowania jej ideałów, w szczególności zaś podkreślania ciągłości trwania tradycji. Ukazywano zatem lata rządów Marii Teresy jako okres militarnych zwycięstw i sukcesów edukacyjnych, jako czasy przemian społecznych i ogólnej prosperity. Niewątpliwie więc można uznać Barona cygańskiego za muzyczne świadectwo epoki, w której powstał, a także muzyczny monument wniesiony na cześć Marii Teresy.

\section{Abstrakt}

Uważana za muzyczny dokument monarchii austro-węgierskiej - operetka Baron cygański (oryginalnie: Der Zigeunerbaron) z 1885 r., skomponowana przez Johanna Straussa II (1825-1899), ukazuje, jak wysoką pozycją cieszyła się w imperium Maria Teresa w długim wieku XIX. Jest to także świetny przykład pielęgnowania - w Wiedniu końca XIX w. - pamięci o jej polityce. Baron cygański to także dzieło wpisujące się w politykę kulturową tamtych czasów, będące specyficzną odpowiedzią na potrzebę stymulowania proobywatelskich postaw (jakże pożądanych w ówczesnej Monarchii). Traktując Barona cygańskiego jako tzw. casestudy, w artykule niniejszym starano się zwrócić uwagę na znaczenie operetki (często ignorowanej, pomijanej lub niedocenianej w dyskusjach naukowych) dla politycznej propagandy oraz kwestii pamięci zbiorowej. Operetki bowiem niejednokrotnie pełniły ważką funkcję w promocji określonej wizji imperium Habsburgów.

archy as curious, laughable exotics, [...], of operetta - a habit whose consequences we are still suffering today. As the same, everything is wrapped up in a phenomenal wealth of beautiful music which will always give these works a certain life even when they themselves are no longer interesting as memories of a great period - brilliant, sad and very strange"). 


\section{Bibliography / Bibliografia}

Bailey D., Vampires in Mythology, New York 2012.

Bellman J., Toward a Lexicon for the Style hongrois, “The Journal of Musicology” 1991, Vol. 9, No. 2. Bercovici K., The story of the Gypsies, New York 1928.

Crittenden C., Durch eine Straußische Operette war man eins geworden: Austro-Hungarian Relations and "Der Zigeunerbaron", "Modern Austrian Literature" 1999, Vol. 32, No. 3.

Ficowski J., Cyganie polscy, Warszawa 1953.

Gartenberg E., Vienna; its musical heritage, Pennsylvania 1968.

Gergely A., Zoltan S., Kiegyezes utan, Budapest 1978.

Hall D., Hellman R., Vampire Legends and Myths, New York 2012.

Hanák P., The Garden and the Workshop: Essays on the Cultural History of Vienna and Budapest, New York 1999.

Hancock I., Introduction, [in:] Gypsies of Eastern Europe, edit. D. Crowe, J. Kolsti, New York 1991.

Hooker L., Turks, Hungarians, and Gypsies on stage: exoticism and auto-exoticism in opera and operetta, "Hungarian Studies" 2013, Vol. 27, No. 2.

Jaspert W., Johann Strauss. Sein Leben, sein Werk, seine Zeit, Berlin 1939.

Jellinek G., History Through the Opera Glass: From the Rise of Caesar to the Fall of Napoleon, New York-London 1994.

Judzińska A., Cesarska kobiecość monarchii naddunajskiej - w cieniu balansującej kontroli. Studium psychospołeczne, "Studia Edukacyjne" 2015, No. 36.

Klotz V., Operette: Porträt und Handbuch einer unerhörten Kunst, Kassel 2004.

Kopyś T., Kwestia narodowościowa na ziemiach Korony świętego Stefana w latach 1867-1918, Kraków 2001.

Kowalczyk R.W., Polityka fiskalna i gospodarcza Józefa II, „Studia z historii społeczno-gospodarczej" 2011, vol. 9.

Křenek E., A Few Words About Johann Strauss, [in:] E. Křenek, Exploring Music. Essays by Ernst Křrenek, London 1966.

Kunce A., Śląsk, masa i XIX wiek, "Anthropos" 2014, vol. 22.

Letellier R.I., Operetta: A Sourcebook, vol. 1, Newcastle 2015.

Małecki M., Ideologiczne podstawy reform terezjańsko-józefińskich, [in:] Krakowskie studia z historii państwa i prawa, edit. W. Uruszczak, D. Malec, M. Mikuła, vol. 3, Kraków 2010.

Mayer A., Steblin R., Johann Strauss: a nineteenth century pop-idol, Wien 1999.

O'Reilly W., Conceptualizing America in Early Modern Central Europe, "Pennsylvania History: A Journal of Mid-Atlantic Studies" 1998, Vol. 65 (Explorations in Early American Culture).

Piotrowska A.G. Miłość cygańska w muzyce - kreacja artystyczna czy poszukiwania wzoru idealnego?, [in:] Romowie w Polsce i w Europie. Od dyskryminacji do tolerancji, edit. A. Bartosz, P. Borek, B. Gryszkiewicz, Kraków 2015.

Piotrowska A.G., Topos muzyki cygańskiej w kulturze europejskiej od końca XVIII do początku XX wieku, Kraków 2011.

Politische Mythen und nationale Identitäten im (Musik-)Theater: Vorträge und Gespräche des Salzburger Symposiums 2001, edit. P. Scobadi, vol. 2, Salzburg 2003.

Robbins S., Dirty Wars: A Century of Counterinsurgency, Stroud 2016.

Rothenberg G.E., The Habsburg Army in the Napoleonic Wars, "Military Affairs" Feb 1973, Vol. 37, No. 1.

Scott D.B., From the Erotic to the Demonic: On Critical Musicology, New York 2003.

Traubner R., Operetta. A Theatrical History, New York 2003. 
Velimirović M., Balkan music history in the seventeenth and eighteenth centuries. Introductory remarks, "Revista de Musicología" 1993, Vol. 16, No. 3 (Del XV Congreso de la Sociedad Internacional de Musicología: Culturas Musicales Del Mediterráneo y sus Ramificaciones), Vol. 3, 1993.

Wechsberg J., The waltz emperors: the life and times and music of the Strauss family, New York 1973.

\section{Internet sources}

http://www.takawiki.com/tiki-index.php?page=The+Gypsy+Baron+\%2F+Rhapsodic + Moon+(Moon+2010) [access on: 2.02.2017].

Article submitted: 15.02.2017; article accepted: 25.03.2017 